\title{
Introducing of some species of genus Allium subgenus Melanocrommyum from Iran as new sources of allicin
}

\author{
Mahboobeh ZARE MEHRJERDI ${ }^{1,2}$, Mahdi MORIDI FARIMANI ${ }^{3}$, Mahdi ABBAS MOHAMMADI ${ }^{3}$, Jalal \\ REZAEI $^{1}$
}

Received; March 02, 2019; accepted March 25, 2020.

Delo je prispelo 02. marca 2019, sprejeto 25. marca 2020

\begin{abstract}
Introducing of some species of genus Allium subgenus Melanocrommyum from Iran as new sources of allicin

Abstract: Allicin is a sulfur compound found in genus $\mathrm{Al}$ lium characterized by numerous biological and pharmacological properties. Melanocrommyum, the second largest subgenus of Allium, has about 10 sections and 82 species in Iran. In this study, allicin content of aerial part, aerial part fresh mass and allicin yield belonging to 17 wild populations of six species of Allium sect. Acanthoprason and Asteroprason growing in different region of Iran, were analyzed. Allicin content evaluation using HPLC method showed its variation between populations from 26.98 to $58.11 \mathrm{mg} \mathrm{g}^{-1} \mathrm{FW}$, also showing that all the tested populations of Allium are rich in allicin. The average of aerial part fresh mass and allicin yield varied between populations from $0.49 \mathrm{~g}$ to $1.66 \mathrm{~g}$ and from $14 \mathrm{mg}$ to $78 \mathrm{mg}$, respectively. The populations were classified in four major groups using dendrogram generated by UPGMA method of cluster analysis. However, grouping of populations was not completely related to species and geographical regions. This study is the first evaluation of allicin content in wild populations of Allium sect. Acanthoprason and Asteroprason in Iran. High amount of allicin in these populations make them a new sources of allicin.

Key words: Acanthoprason; Asteroprason; medicinal plant; population; variation; allicin content
\end{abstract}

Uvajanje nekaterih vrst iz rodu Allium, podrodu Melanocrommyum iz Irana kot novih virov alicina

Izvleček: Alicin je žveplo vsebujoča snov v rodu Allium $\mathrm{s}$ številnimi biološkimi in farmakološkimi lastnostmi. Podrod Melanocrommyum je drugi največji podrod v rodu Allium, v Iranu z okoli 10 sekcijami in 82 vrstami. V raziskavi so bili analizirani nadzemni deli na vsebnost alicina in svežo maso pri 17 divjih populacijah šestih vrst iz rodu Allium, sekcij. Acanthoprason in Asteroprason, ki rastejo na različnih območjih Irana. Vsebnost alicina, ovrednotena s HPLC metodo je pokazala razlike med populacijami v razponu od 26,98 do $58,11 \mathrm{mg}$ $\mathrm{g}^{-1}$ na svežo maso, kar kaže, da so vse populacije preiskušenih vrst bogate na alicinu. Poprečna sveža masa in vsebnost alicina nadzemnih delov je med populacijami variirala od $0,49 \mathrm{~g}$ do $1,66 \mathrm{~g}$ in od $14 \mathrm{mg}$ do $78 \mathrm{mg}$. Z generiranjem dendrograma po UPGMA metodi in klasterski analizi so bile populacije združene v 4 glavne skupne. Grupiranje populacij se ni popolnoma ujemalo $\mathrm{z}$ vrstami in geografskimi regijami izvora. Ta raziskava je prva v Iranu, ki je ovrednotila vsebnost alicina v divjih populacijah vrst iz rodu Allium, Acanthoprason in Asteroprason. Zaradi velike vsebnosti alicina so vrste iz teh popuacij lahko njegov nov naravni vir.

Ključne besede: Acanthoprason; Asteroprason; zdravilne rastline; populacija; variabilnost; vsebnost alicina

1 University of Tehran, College of Aburaihan, Department of Horticulture, Tehran, Iran

2 Corresponding author, e-mail: mzarem@ut.ac.ir

3 Shahid Beheshti University, Medicinal Plants and Drug Research Institute, Department of Phytochemistry, Tehran, Iran 


\section{INTRODUCTION}

Plants of the genus Allium belonging to monocotyledonous flowering plants comprise more than 900 accepted species, with main center of diversity in the eastern Mediterranean area, Southwest and Central Asia (Fritsch \& Abbasi, 2013). Allium species have been used for centuries as vegetables, as well as medicinal plants. Several studies have been conducted showing Allium's therapeutic properties as well as numerous reports referring to their antioxidant, antibacterial, antifungal, antiparasitic, antiseptic, anti-inflammatory, anticancer, antidiabetic, cardioprotective, antiatherosclerosis, hepatoprotective and immunomodulatory properties (Benkeblia, 2004; Galeone et al., 2006; Rizwani \& Shareef, 2011; Feng et al., 2012; Lu et al., 2012; Nicastro et al., 2015; Sobolewska et al., 2015; Huang et al., 2016; Rad et al., 2017; Zeng et al., 2017). Most of medicinal properties of Alliums are mainly attributed to phenolic (like flavonoids: kaempferol, myricetin and quercetin derivatives) and sulfur-containing compounds and beneficial elements such as selenium (Omar \& Al-Wabel, 2010; Nwachukwu \& Slusarenko, 2014; Soto et al., 2016). Organic sulphur compounds like alliin, allicin, allyl sulfide, (E)-ajoene, (Z)-ajoene and 1,2-vinyldithiin are responsible for odor, flavor and most of biological activities of Alliums (Block, 1992; Benkeblia \& Lanzotti, 2007). Among these, allicin (diallylthiosulfinate) has received more attention due to its significant human health benefits (Oommen et al., 2004; Rahman, 2007; Borlinghaus et al., 2014; Ye et al., 2016).

Allicin's structure and activities were described by Cavallito and Bailey in 1944 for the first time (Cavallito \& Bailey, 1944). This unstable sulfur compound is composed from alliin by the action of alliinase released from vacuoles upon crushing or damaging Allium tissues (Jones et al., 2007). Allicin is now clearly accepted as a biologically active compound, and several documents have been published in this field (Ali et al., 2000; Li et al., 2010; Wallock-Richards et al., 2014; Gruhlke et al., 2017). Garlic (Allium sativum L.) is a main source of allicin among cultivated Alliums. Nevertheless, there are many wild Allium species that may have potentially some levels of allicin which needs investigation.

Melanocrommyum, the second largest subgenus of Allium, comprises about 10 sections and 82 species in Iran (Fritsch \& Abbasi, 2013). Some species in Acanthoprason and Asteroprason, two sections in this subgenus, are used by folk peoples as wild leafy vegetable and medicinal herbs. These plants have specific smell like garlic. In spite of long local traditional usages, there is no research on their beneficial compounds like allicin. These species are threatened with extinction because of wildharvesting as the only way to reach them. Awareness and knowledge about their potent in production of healthy metabolites is needed for domestication and breeding of these species.

In this study allicin content of 17 wild populations belonging to six species of Allium sect. Acanthoprason and Asteroprason which were collected from different regions of Iran, as a central part of diversity of this genus, were investigated.

\section{MATERIALS AND METHODS}

\subsection{PLANT MATERIAL}

Seventeen populations of Allium including six species of sect. Acanthoprason and Asteroprason from diverse geographical origin which were described by Fritsch and Abbasi (2013) were collected during the flowering stage. Table 1 gives the geographical location of populations. All plants were cut $1 \mathrm{~cm}$ above ground, weighted and kept in a freezer at $-80^{\circ} \mathrm{C}$.

\subsection{SAMPLE PREPARATION}

Allicin was extracted from randomly ten plants of each population in two replications according to Baghalian et al. (2005). In brief, each $800 \mathrm{mg}$ powder sample was placed in an ultrasonic bath at $4{ }^{\circ} \mathrm{C}$ for 5 min with $20 \mathrm{ml}$ of distilled water. Tubes were incubated for $30 \mathrm{~min}$ at room temperature. The supernatant were then separated by centrifuging at $6000 \mathrm{~g}$ for $30 \mathrm{~min}$. The supernatant $(10 \mathrm{ml})$ were added to $15 \mathrm{ml}$ of solution which contains $1 \%(\mathrm{v} / \mathrm{v})$ solution of anhydrous formic acid and metha$\mathrm{nol}(4: 6)$ and centrifuged at $6000 \mathrm{~g}$ for $5 \mathrm{~min}$. The extracts were analyzed as quickly as possible.

$20 \mathrm{mg}$ butyl parahydroxybenzoate in $100 \mathrm{ml}$ of methanol-water (50:50) was used as internal standard. $0.5 \mathrm{ml}$ of internal standard was added to supernatant and make up the volume to $10 \mathrm{ml}$ and $20 \mu \mathrm{l}$ of it was injected into the HPLC.

\subsection{DETERMINATION OF ALLICIN}

The allicin were determined according to the method of Baghalian et al. (2005). The HPLC analysis was carried out on a Knauer HPLC system (Berlin, Germany) equipped with a Knauer C18 column $(25 \mathrm{~cm} \times 4.6 \mathrm{~mm})$ and a PDA detector. The mobile phase was methanolwater $(50: 50)$ at a flow rate of $0.7 \mathrm{ml} \mathrm{min}^{-1}$. Elution was monitored at $254 \mathrm{~nm}$. The percentage of allicin was calculated by using the following equation: 


$$
\text { Allicin }(\%)=" \mathrm{~s}_{1} \mathrm{~m}_{2} * 22.75 " / \mathrm{s}_{2} \mathrm{~m}_{1} "
$$

Where $s_{1}$ and $s_{2}$ are the area of the peak corresponding to allicin and internal standard and $\mathrm{m}_{1}$ and $\mathrm{m}_{2}$ are the mass of the Allium powder and butyl parahydroxybenzoate in internal standard solution, respectively. The allicin content was expressed as $\mathrm{mg} \mathrm{g}^{-1}$ FM.

Mean allicin yield of each population (per plant) were calculated by using percentage of allicin and aerial part fresh mass.

\subsection{DATA ANALYSIS}

Pearson correlation and cluster analyses (UPGMA) were carried out on the data of allicin content and aerial part fresh weight using the statistical software SPSS (SPSS Inc., Chicago, USA).

\section{RESULTS AND DISCUSSION}

The aerial part allicin content of 17 populations of Allium belonging to Acanthoprason and Asteroprason sections collected from different regions of Iran are shown in Figure 1. The percentage of allicin content varied from 26.98 to $58.11 \mathrm{mg} \mathrm{g}^{-1} \mathrm{FM}$, where the highest content was found for Shen Jari population of $A$. pseudobodeanum, followed by Dehdasht of A. minutiflorum (57.95 $\mathrm{mg} \mathrm{g}^{-1}$ FM), Pir Baba Ali of A. subakaka (56.87 $\mathrm{mg} \mathrm{g}^{-1} \mathrm{FM}$ ) and Shirpala, another population of $A$. pseudobodeanum (55.94 $\mathrm{mg} \mathrm{g}^{-1} \mathrm{FM}$ ), while the lowest content belonged to Taze Abad Oryeh population of A. kurdistanicum, followed by Vali Abad of $A$. derderianum (27.42 $\mathrm{mg} \mathrm{g}^{-1} \mathrm{FM}$ ).

Variation in allicin content of different ecotypes of garlic as a main source of this valuable metabolite is reported in previous studies (Baghalian et al., 2005; Wang et al., 2014; Mostafa et al., 2015; Panahandeh et al., 2016). Allicin content of 212 accessions of garlic from different

Table 1: Allium populations including six species of sect. Acanthoprason and Asteroprason collected from various locations of Iran

\begin{tabular}{|c|c|c|c|c|c|c|}
\hline $\begin{array}{l}\text { Pop. } \\
\text { no. }\end{array}$ & Section & Species & Location (Province) & $\begin{array}{l}\text { Latitude } \\
(\mathrm{N})\end{array}$ & $\begin{array}{l}\text { Longitude } \\
\text { (E) }\end{array}$ & $\begin{array}{l}\text { Altitude } \\
(\mathrm{m})\end{array}$ \\
\hline 1 & Acanthoprason & A. derderianum Regel. & Dareh Oson (Tehran) & $35^{\circ} 51^{\prime} 248^{\prime \prime}$ & $51^{\circ} 25^{\prime} 786^{\prime \prime}$ & 2645 \\
\hline 2 & Acanthoprason & A. derderianum Regel. & Vali Abad (Mazandaran) & $36^{\circ} 18^{\prime} 856^{\prime \prime}$ & $51^{\circ} 11^{\prime} 1^{\prime \prime}$ & 2421 \\
\hline 3 & Acanthoprason & A. derderianum Regel. & Kochka (Mazandaran) & $36^{\circ} 18^{\prime} 232^{\prime \prime}$ & $51^{\circ} 04^{\prime} 53^{\prime \prime}$ & 2248 \\
\hline 4 & Acanthoprason & A. derderianum Regel. & Vandarin (Mazandaran) & $36^{\circ} 22^{\prime} 55^{\prime \prime}$ & $51^{\circ} 1^{\prime} 41^{\prime \prime}$ & 2926 \\
\hline 5 & Acanthoprason & $\begin{array}{l}\text { A. kurdistanicum Maroofi } \\
\text { \& R.M. Fritsch }\end{array}$ & Taze Abad Oryeh (Kurdistan) & $35^{\circ} 7^{\prime} 42^{\prime \prime}$ & $47^{\circ} 40^{\prime} 309^{\prime \prime}$ & 2332 \\
\hline 6 & Acanthoprason & A. minutiflorum Regel. & $\begin{array}{l}\text { Dehdasht (Kohgiluyeh and } \\
\text { Boyer-Ahmad) }\end{array}$ & $30^{\circ} 50^{\prime} 315^{\prime \prime}$ & $50^{\circ} 33^{\prime} 067^{\prime \prime}$ & 1920 \\
\hline 7 & Acanthoprason & $\begin{array}{l}\text { A. subakaka Razyfard \& } \\
\text { Zarre }\end{array}$ & Pir Baba Ali (Kurdistan) & $35^{\circ} 6^{\prime} 17^{\prime \prime}$ & $47^{\circ} 39^{\prime} 26^{\prime \prime}$ & 2351 \\
\hline 8 & Acanthoprason & $\begin{array}{l}\text { A. subakaka Razyfard \& } \\
\text { Zarre }\end{array}$ & Jame Shoran (Kurdistan) & $35^{\circ} 5^{\prime} 733^{\prime \prime}$ & $47^{\circ} 39^{\prime} 175^{\prime \prime}$ & 2318 \\
\hline 9 & Acanthoprason & $\begin{array}{l}\text { A. subakaka Razyfard \& } \\
\text { Zarre }\end{array}$ & Ghalelan (Kurdistan) & $35^{\circ} 4^{\prime} 965^{\prime \prime}$ & $47^{\circ} 39^{\prime} 245^{\prime \prime}$ & 2618 \\
\hline 10 & Asteroprason & A. elburzense W. & Band e Yakhchal (Tehran) & $35^{\circ} 50^{\prime} 648^{\prime \prime}$ & $51^{\circ} 25^{\prime} 775^{\prime \prime}$ & 2277 \\
\hline 11 & Asteroprason & A. elburzense W. & $\begin{array}{l}\text { Emamzadeh Ebrahim (Teh- } \\
\text { ran) }\end{array}$ & $35^{\circ} 50^{\prime} 5^{\prime \prime}$ & $51^{\circ} 25^{\prime} 10^{\prime \prime}$ & 2120 \\
\hline 12 & Asteroprason & A. elburzense W. & Kamelat (Tehran) & $35^{\circ} 44^{\prime} 514^{\prime \prime}$ & $52^{\circ} 04^{\prime} 594^{\prime \prime}$ & 2372 \\
\hline 13 & Asteroprason & A. elburzense W. & Abnik (Tehran) & $35^{\circ} 51^{\prime} 353^{\prime \prime}$ & $51^{\circ} 25^{\prime} 414^{\prime \prime}$ & 2567 \\
\hline 14 & Asteroprason & A. elburzense W. & Ghabre Oros (Tehran) & $35^{\circ} 51^{\prime} 618^{\prime \prime}$ & $51^{\circ} 25^{\prime} 25^{\prime \prime}$ & 2821 \\
\hline 15 & Asteroprason & A. elburzense W. & $\begin{array}{l}\text { Kandovan Tunnel (Mazan- } \\
\text { daran) }\end{array}$ & $36^{\circ} 9^{\prime} 56^{\prime \prime}$ & $51^{\circ} 19^{\prime} 16^{\prime \prime}$ & 2672 \\
\hline 16 & Asteroprason & $\begin{array}{l}\text { A. pseudobodeanum R.M. } \\
\text { Fritsch \& Matin }\end{array}$ & Shen Jari (Tehran) & $35^{\circ} 4^{\prime} 50^{\prime \prime}$ & $52^{\circ} 50^{\prime} 372^{\prime \prime}$ & 2290 \\
\hline 17 & Asteroprason & $\begin{array}{l}\text { A. pseudobodeanum R.M. } \\
\text { Fritsch \& Matin }\end{array}$ & Shirpala (Tehran) & $35^{\circ} 51^{\prime} 171^{\prime \prime}$ & $51^{\circ} 25^{\prime} 458^{\prime \prime}$ & 2515 \\
\hline
\end{tabular}




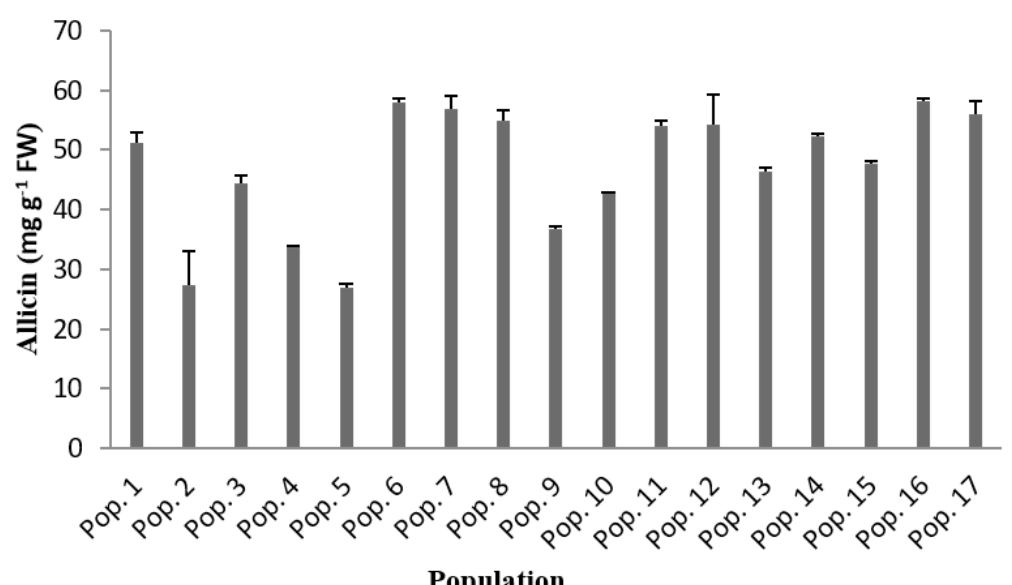

Figure 1: Schematic diagram representing the percentage of aerial part allicin in different populations of Allium belonging to Acanthoprason and Asteroprason sections from Iran

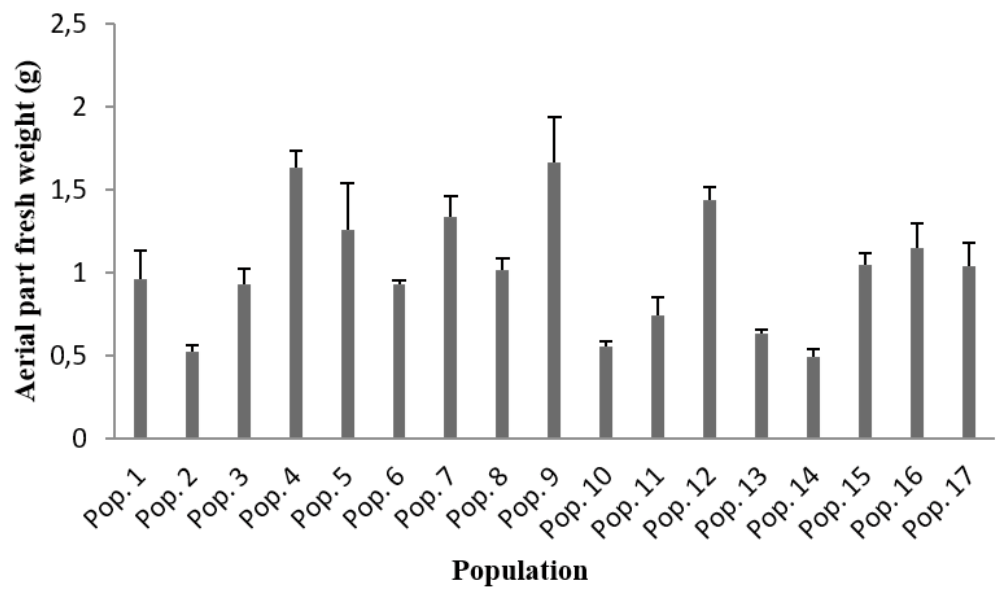

Figure 2: The average of aerial part fresh mass of different populations of Allium belonging to Acanthoprason and Asteroprason sections from Iran

provinces and areas of China ranged from 0.81 to $3.01 \%$ (Wang et al., 2014). In an investigation of 24 Iranian garlic ecotypes from different areas, allicin was the highest in a local selected clone from northeast of Iran (13\% DW) (Baghalian et al., 2005). In the present work, high amount of allicin (2.69-5.81 \% FM) was found in all the tested populations of Allium. So it was indicated that all studied populations are suitable for allicin production and pharmaceutical usage.

The average of aerial part fresh mass per plant in these populations ranged from $0.49 \mathrm{~g}$ in Ghabre Oros $(A$. elburzense) to $1.66 \mathrm{~g}$ in Ghalelan population (A. subakaka) (Figure 2). Variation in morphological parameters between species, populations and genotypes of Alliums is supported by previous literatures (Panthee et al., 2006; Karpaviciene, 2012; Khosa et al., 2014; Wang et al., 2014;
Shiga et al., 2015; Silva et al., 2015; Hirata et al., 2016; Jafari et al., 2017).

Based on the obtained results, there was no correlation between percentage of allicin and aerial part fresh masst and these two characters were affected by species and environmental conditions.

Calculation of allicin yield of aerial part for each population shown in Figure 3 indicated that the average of allicin yield was the highest in Kamelat population ( $A$. elburzense) $(78 \mathrm{mg})$ and the lowest in Vali Abad (A. derderianum) (14 mg).

Due to variation of aerial part fresh mass among population, calculation of allicin yield appears to be a good parameter for evaluation of populations and finding the promising populations which can be selected for domesticating and breeding programs. Based on the results, Kamelat followed by Pir Baba Ali population have 


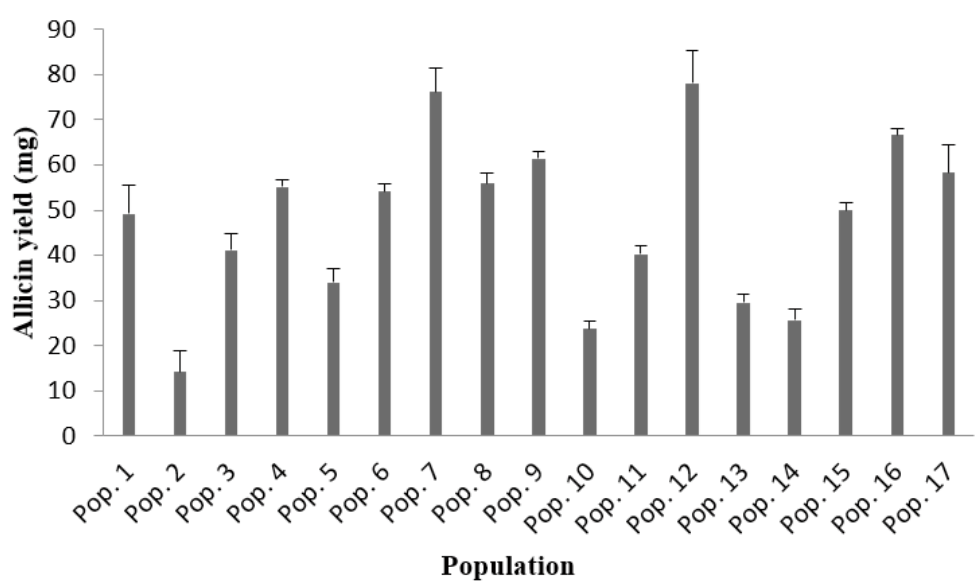

Figure 3: The average of aerial part allicin yield of different populations of Allium belonging to Acanthoprason and Asteroprason sections from Iran

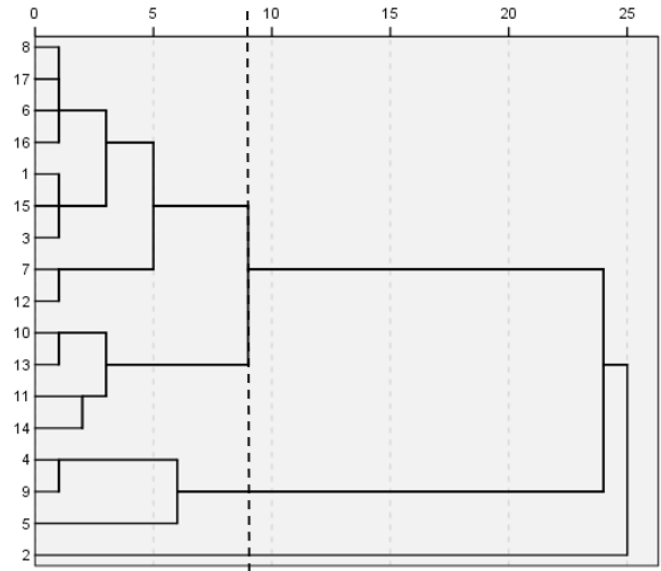

Figure 4: Cluster analysis of different populations of Allium belonging to Acanthoprason and Asteroprason sections from Iran using UPGMA method

the highest allicin yield and could be suitable candidates for breeding.

Dendrogram generated by UPGMA method of cluster analysis is presented in Figure 4. By applying cluster analysis, four main groups and some subgroups were evident. Jame Shoran (A. subakaka), Shirpala (A. pseudobodeanum), Dehdasht (A. minutiflorum), Shen Jari (A. pseudobodeanum), Dareh Oson (A. derderianum), Kandovan Tunnel (A. elburzense), Kochka (A. derderianum), Pir Baba Ali (A. subakaka), Kamelat (A. elburzense) populations were placed in cluster I. Four populations of A. elburzense from Tehran province (Band e Yakhchal, Abnik, Emamzadeh Ebrahim and Ghabre Oros) were assigned to cluster II. Cluster III was composed of Vandarin (A. derderianum), Ghalelan (A. subakaka) and Taze Abad Oryeh (A. kurdistanicum) populations. Finally, Vali Abad (A. derderianum) population formed cluster IV.
Grouping of the populations were not completely related to species and geographical regions.

\section{CONCLUSIONS}

This study is the first evaluation of allicin content in wild populations of Allium sect. Acanthoprason and Asteroprason in Iran. Our results showed that these wild populations present considerable variation in percentage of aerial part allicin, aerial part fresh mass and allicin yield. High amount of allicin in these populations make them new sources of allicin. Conservation, domestication and breeding of studied populations are critical to exploitation and prevention of danger of their extinction. Allicin rich plants are desirable for medical industry and 
Kamelat and Pir Baba Ali populations are good candidates for these purposes.

\section{ACKNOWLEDGMENT}

The work was funded by the Iran National Science Foundation (INSF) and the author would like to thank the INSF for this support.

\section{REFERENCES}

Ali, M., Al-Qattan, K.K., Al-Enezi, F., Khanafer, R.M.A. and Mustafa, T. (2000). Effect of allicin from garlic powder on serum lipids and blood pressure in rats fed with a high cholesterol diet. Prostaglandins, Leukotrienes and Essential Fatty Acids, 62(4), 253-259. https://doi.org/10.1054/ plef.2000.0152

Baghalian, K., Ziai, S.A., Naghavi, M.R., Badi, H.N. and Khalighi, A. (2005). Evaluation of allicin content and botanical traits in Iranian garlic (Allium sativum L.) ecotypes. Scientia Horticulturae, 103(2), 155-166. https://doi.org/10.1016/j. scienta.2004.07.001

Benkeblia, N. (2004). Antimicrobial activity of essential oil extracts of various onions (Allium cepa) and garlic (Allium sativum). LWT-Food Science and Technology, 37(2), 263-268. https://doi.org/10.1016/j.lwt.2003.09.001

Benkeblia, N. and Lanzotti, V. (2007). Allium thiosulfinates: chemistry, biological properties and their potential utilization in food preservation. Food, 1(2), 193-201.

Block, E. (1992). Theorganosulfur chemistry of the genus $\mathrm{Al}$ lium-implications for the organic chemistry of sulfur. Angewandte Chemie International Edition, 31(9), 1135-1178. https://doi.org/10.1002/anie.199211351

Borlinghaus, J., Albrecht, F., Gruhlke, M.C.H., Nwachukwu, I.D. and Slusarenko, A.J. (2014). Allicin: chemistry and biological properties. Molecules, 19(8), 12591-12618. https:// doi.org/10.3390/molecules190812591

Cavallito, C.J. and Bailey, J.H. (1944). Allicin, the antibacterial principle of Allium sativum. I. Isolation, physical properties and antibacterial action. Journal of American Chemical Society, 66(11), 1950-1951. https://doi.org/10.1021/ ja01239a048

Feng, Y., Zhu, X., Wang, Q., Jiang, Y., Shang, H., Cui, L. and Cao, Y. (2012). Allicin enhances host pro-inflammatory immune responses and protects against acute murine malaria infection. Malaria Journal, 11(1), 268-276. https://doi. org/10.1186/1475-2875-11-268

Fritsch, R.M. and Abbasi, M. (2013). A taxonomic review of Alliumsubg.Melanocrommyum in Iran. Leibniz-InstitutfürPflanzengenetik und Kulturpflanzenforschung, Gatersleben (IPK) (240 pp).

Galeone, C., Pelucchi, C., Levi, F., Negri, E., Franceschi, S., Talamini, R., Giacosa, A. and La Vecchia, C. (2006). Onion and garlic use and human cancer. The American Journal of Clinical Nutrition, 84(5), 1027-1032. https://doi.org/10.1093/ ajcn/84.5.1027
Gruhlke, M.C.H., Nicco, C., Batteux, F. and Slusarenko, A.J. (2017). The effects of allicin, a reactive sulfur species from garlic, on a selection of mammalian cell lines. Antioxidants, 6(1), 1-16. https://doi.org/10.3390/ antiox6010001

Hirata, S., Abdelrahman, M., Yamauchi, N. and Shigyo, M. (2016). Diversity evaluation based on morphological, physiological and isozyme variation in genetic resources of garlic (Allium sativum L.) collected worldwide. Genes and Genetic Systems, 91(3), 161-173. https://doi.org/10.1266/ ggs.15-00004

Huang, H., Jiang, Y., Mao, G., Yuan, F., Zheng, H., Ruan, Y. and $\mathrm{Wu}, \mathrm{T}$. (2016). Protective effects of allicin on streptozotocin-induced diabetic nephropathy in rats. Journal of the Science of Food and Agriculture, 97(4), 1359-1366. https:// doi.org/10.1002/jsfa.7874

Jafari, S., Hassandokht, M.R., Taheri, M. and Kashi, A. (2017). Genetic diversity and taxonomic studies of Allium Akaka and A. Elburzensenative to Iran using morphological characters. Journal of Horticultural Research, 25(1), 99-115. https://doi.org/10.1515/johr-2017-0011

Jones, M.G., Collin, H.A., Tregova, A., Trueman, L., Brown, L., Cosstick, R., Hughes, J., Milne, J., Wilkinson, M.C. and Tomsett, A.B. (2007). The biochemical and physiological genesis of alliin in garlic. Medicinal and Aromatic Plant Science and Biotechnology, 1(1), 21-24.

Karpaviciene, B. (2012). Morphological, reproductive and karyological variability in Allium oleraceum in Lithuania. Biologia, 67(2), 278-283. https://doi.org/10.2478/s11756012-0003-3

Khosa, J.S., Dhatt, A.S. and Negi, K.S. (2014). Morphological characterization of Allium spp. Using multivariate analysis. Indian Journal of Plant Genetic Resources, 27, 24-27. https:// doi.org/10.5958/0976-1926.2014.00020.5

Li, W., Wang, D., Song, G., Zuo, C., Qiao, X. and Qin, S. (2010). The effect of combination therapy of allicin and fenofibrate on high fat diet-induced vascular endothelium dysfunction and liver damage in rats. Lipids in Health and Disease, 9(1), 131-137. https://doi.org/10.1186/1476-511X-9-131

Lu, Y., He, Z., Shen, X., Xu, X., Fan, J., Wu, S. and Zhang, D. (2012). Cholesterol-lowering effect of allicin on hypercholesterolemic ICR mice. Oxidative Medicine and Cellular Longevity, 2012, 1-6. https://doi.org/10.1155/2012/489690

Mostafa, H.H.A., Haiping, W., Xinyan, L. and Xixiang, L. (2015). Impact of genetic factor and geographical location on Allicin content of garlic (Allium sativum) germplasm from Egypt and China. International Journal of Agriculture and Biology, 17(1), 156-162.

Nicastro, H.L., Ross, S.A. and Milner, J.A. (2015). Garlic and onions: their cancer prevention properties. Cancer Prevention Research, 8(3), 181-189. https://doi.org/10.1158/19406207.CAPR-14-0172

Nwachukwu, I.D. and Slusarenko, A.J. (2014). Thiosulfinates, organic polysulfanes, and related compounds: from an unusual chemistry toward a wealth of potential applications. In: C. Jacob, G. Kirsch, A. Slusarenko, P.G. Winyard, T. Burkholz (Eds.), Recent Advances in Redox Active Plant and Microbial Products. (pp. 265-288). Springer. https://doi. org/10.1007/978-94-017-8953-0_10

Omar, S.H. and Al-Wabel, N.A. (2010). Organosulfur com- 
pounds and possible mechanism of garlic in cancer. Saudi Pharmaceutical Journal, 18(1), 51-58. https://doi. org/10.1016/j.jsps.2009.12.007

Oommen, S., Anto, R.J., Srinivas, G. and Karunagaran, D. (2004). Allicin (from garlic) induces caspase-mediated apoptosis in cancer cells. European Journal of Pharmacology, 485(1), 97 103. https://doi.org/10.1016/j.ejphar.2003.11.059

Panahandeh, J., Farhadi, N., Azar, A.M. and Salte, S.A. (2016). Evaluation of Persian Shallot (Allium hirtifolium) Ecotypes for Phytochemical Components and Antioxidant Activity. Journal of Medicinal Plants and By-products, 2, 217-226.

Panthee, D.R., Kc, R.B., Regmi, H.N., Subedi, P.P., Bhattarai, S. and Dhakal, J. (2006). Diversity analysis of garlic (Allium sativum L.) germplasms available in Nepal based on morphological characters. Genetic Resources and Crop Evolution, 53(1), 205-212. https://doi.org/10.1007/s10722-0046690-Z

Rad, H.I., Arzanlou, M., Omid, M.R., Ravaji, S. and Doghaheh, H.P. (2017). Effect of culture media on chemical stability and antibacterial activity of allicin. Journal of Functional Foods, 28, 321-325. https://doi.org/10.1016/j.jff.2016.10.027

Rahman, M.S. (2007). Allicin and other functional active components in garlic: health benefits and bioavailability. International Journal of Food Properties, 10(2), 245-268. https:// doi.org/10.1080/10942910601113327

Rizwani, G.H. and Shareef, H. (2011). Genus Allium: the potential nutritive and therapeutic source. Journal of Pharmacy and Nutrition Sciences, 1(2), 158-165. https://doi. org/10.6000/1927-5951.2011.01.02.11

Shiga, Y., Tsutsui, S. and Mikami, T. (2015). Morphological characteristics and ancestry of Japanese garlic clones-An overview. Journal of Applied Horticulture, 17(3), 210-212. https://doi.org/10.37855/jah.2015.v17i03.39
Silva, V.C.P.d., Bettoni, M.M., Bona, C. and Foerster, L.A. (2015). Morphological and chemical characteristics of onion plants (Allium cepa L.) associated with resistance to onion thrips. Acta Scientiarum Agronomy, 37(1), 85-92. https://doi.org/10.4025/actasciagron.v37i1.17436

Sobolewska, D., Podolak, I. and Makowska-Was, J. (2015). Allium ursinum: botanical, phytochemical and pharmacological overview. Phytochemistry Reviews, 14(1), 81-97. https:// doi.org/10.1007/s11101-013-9334-0

Soto, V.C., Gonzalez, R.E., Sance, M.M. and Galmarini, C.R. (2016). Organosulfur and phenolic content of garlic (Allium sativum L.) and onion (Allium cepa L.) and its relationship with antioxidant activity, VII International Symposium on Edible Alliaceae 1143, (pp. 277-290). Turkey. https://doi. org/10.17660/ActaHortic.2016.1143.39

Wallock-Richards, D., Doherty, C.J., Doherty, L., Clarke, D.J., Place, M., Govan, J.R.W. and Campopiano, D.J. (2014). Garlic revisited: antimicrobial activity of allicin-containing garlic extracts against Burkholderiacepacia complex. PLoS One, 9(12), e112726. https://doi.org/10.1371/journal. pone.0112726

Wang, H., Li, X., Shen, D., Oiu, Y. and Song, J. (2014). Diversity evaluation of morphological traits and allicin content in garlic (Allium sativum L.) from China. Euphytica, 198(2), 243-254. https://doi.org/10.1007/s10681-014-1097-1

Ye, H., Ye, G., Jiang, J., Xu, X. and Wu, C. (2016). Anti-proliferative effect of allicin on human hepatoma HepG2 cells. Biomedical Research, 27(1), 195-198.

Zeng, Y., Li, Y., Yang, J., Pu, X., Du, J., Yang, X., Yang, T. and Yang, S. (2017). Therapeutic role of functional components in Alliums for preventive chronic disease in human being. Evidence-Based Complementary and Alternative Medicine, 2017, 1-13. https://doi.org/10.1155/2017/9402849 